\title{
Access and Availability of Diagnostic Services: The Experiences of Women with Breast Cancer in Jalisco, Mexico
}

Igor Martín Ramos Herrera ${ }^{*}$, Miguel Ernesto González Castañeda ${ }^{2}$, Cristóbal García Sandoval ${ }^{3}$, Antonio Reyna Sevilla $^{4}$, Rosa María Valdez López ${ }^{5}$, Armando Morales Fernández ${ }^{6}$, Juan de Dios Robles Pastrana ${ }^{7}$, Samantha López Águila ${ }^{8}$ and Zazil Camet ${ }^{9}$

${ }^{1} \mathrm{PhD}$ in Education, University of Guadalajara, Mexico

${ }^{2} \mathrm{PhD}$ in Sciences of Public Health, University of Guadalajara, Mexico

${ }^{3}$ Master's in sciences of Public Health, University of Guadalajara, Mexico

${ }^{4}$ Master's in sciences of Public Health, University of Guadalajara, Mexico

${ }^{5}$ Master's in sciences of Public Health, University of Guadalajara, Mexico

${ }^{6}$ Master's in sciences of Public Health, University of Guadalajara, Mexico

${ }^{7}$ Master's in Mathematics, University of Guadalajara, Mexico

${ }^{8}$ Epidemiologist. Instituto Jalisciense de Cancerología, Mexico

${ }^{9}$ Undergraduate student in History, University of Guadalajara, Mexico

Submission: June 03, 2019; Published: July 05, 2019

*Corresponding author: Igor Martín Ramos Herrera, PhD in Education, University of Guadalajara, Mexico

\begin{abstract}
This case report describes the experience lived by women with breast cancer in the state of Jalisco, Mexico to access diagnostic services. Data was collected via a mixed design study, 5 randomly selected women attending the State's Cancer Institute were interviewed and their experiences were analyzed using the ATLAS.ti program. Results showed sharp differences between the availability of diagnostic services in rural and urban communities. 1 week to 2 years delays were identified between the first doctor visit and definitive diagnosis. Regardless of the difficulties of access and availability, participants considered they received a timely diagnosis. These results may support the geographical redistribution policies of screening, referrals and care.
\end{abstract}

Keywords: Breast neoplasms; Health Services Accessibility; Early Detection of Cancer

\section{Introduction}

Breast cancer is a severe threat to health worldwide and especially for Mexican women. In Mexico, more than five thousand deceases were reported in 2013, and breast cancer is one of the most frequent malignant tumors among women 20 years and older. The diagnosis performed at early stages (I and IIa) has proved its effectiveness to treat breast cancer in a timely manner, reduce mortality and improve patient survival. Although effective access to health services is crucial to achieve early diagnosis, the woman's role in self-exam is decisive, as well as visits to the health care units or mammogram services, ultrasound, laboratory, and access to third level services, to conduct the studies that define the diagnosis and treatment. Hence, the most significant delay intervals on this period, according to Webber et al. [1]. conceptual framework are attributable to the patient and the diagnosis. In other words, the first delay interval occurs from the moment women detect initial symptoms to the moment they have the first visit to family doctor; while the second delay interval occurs from the first medical encounter to the moment the definite diagnosis is performed.

In Mexico there is not always availability and accessibility suitable to diagnostic services, in accordance with the access model of Penchansky \& Thomas [2], due to differences in the location of such services between rural and urban areas, in spite of adequate communication routes, affordable transportation services and appropriate costs of mobility to access them. 


\section{Objectives}

This case report describes the experience of five women with breast cancer to access diagnostic services in the state of Jalisco, Mexico, and how they lived a delay in health care delivery and diagnosis.

\section{Methods}

The results of the qualitative phase of a mixed design study are presented. 110 women were randomly selected among more than 4,300 patients with breast cancer treated at the State's Cancer Institute (Instituto Jalisciense de Cancerología) between 2013 and 2017, all of them were 20 years and older, they had a diagnosis of breast cancer performed under the Mexican Official Standard and National Comprehensive Cancer Network criteria, and their habitual residence at the moment of diagnosis was at the state of Jalisco.

In-depth interviews were conducted to the first five women that accepted to participate, supported on a semi-structured interview guide and non-participant observation through an observation guide to collect information about the towns of residence of the participants. Participants were contacted via phone call to invite them to the study. A home visit was scheduled for each participant between September and December 2017, and informed consent was obtained. Interviews were tape-recorded and their duration was 90 minutes in average.

The audio files were directly analysed using the ATLAS. ti software. The analysis technique was theoretical/thematic, executed by two of the researchers, who contrasted the identified themes according to the access and delay interval models.

\section{Results}

Regarding the topics of accessibility and availability of the access model to health services Penchansky \& Thomas [2], the categories of type, cost, and time of transportation, and distance to the health care units were analyzed. Participants used mobilized in different ways, depending on their destination: health care unit, mammogram-ultrasound service or third-level hospital for diagnosis, they travelled by walking, by bus, by rented car, by borrowing a relative's car or their own vehicle in the lowest number of cases; most of the time in a combination of several transportation types due to the distance for the services location.
For this reason, variation of time and cost of transportation was evident, from just a few minutes and zero cost, to those with the closest to home services, to two days and several thousands of pesos to access the state's diagnosis and treatment services. In terms of the availability category, they experimented sharp differences between the urban and rural communities in relation to the location of the clinics, hospitals, laboratory and consultancy studies, as well as medical and nursing personnel availability.

There exist greater problems for the participants who reside in rural areas because they have to travel to big cities that hold the medical and mammogram services, while all of them have to attend to the Cancer Institute located in the city of Guadalajara, this mobilization imposes greater efforts to get there. According to the delay intervals model in health care Webber et al. [1] almost all the participants mentioned they visited the physician from a few days until one month after identifying there was something abnormal on their breasts; however a greater delay was identified in the time between the first doctor visit and the definitive diagnosis, that is to say, from one to three weeks until two years to the moment of final diagnosis.

\section{Discussion}

We identified how these women lived the process of access and availability of health care services when there is a suspicion of cancer, nevertheless all the participants consider their diagnosis was conducted in a timely manner, one of them relates: "[they] detected the cancer on time... I am still here". In other words, regardless of the difficulties of access and availability, what they value most is the fact of being alive, treating their illness and endeavouring to move forward. These results can be useful to decision-makers at considering these women's the point of view in respect of the difficulties they experiment to get to the diagnostic services, as well as attaining their medications and treatment. Also, these results may support the geographical re-distribution policies of screening, referral services and care delivery.

\section{References}

1. Webber C, Jiang L, Grunfeld E, Groome PA (2016) Identifying predictors of delayed diagnoses in symptomatic breast cancer: a scoping review. European Journal of Cancer Care 26(2): 1-13.

2. Penchansky R, Thomas, JW (1981) The concept of access: definition and relationship to consumer satisfaction. Medical Care 19(2): 127140 .

\begin{tabular}{l} 
Your next submission with Juniper Publishers \\
will reach you the below assets \\
- Quality Editorial service \\
- Swift Peer Review \\
- Reprints availability \\
- E-prints Service \\
- Manuscript Podcast for convenient understanding \\
- Global attainment for your research \\
- Manuscript accessibility in different formats \\
( Pdf, E-pub, Full Text, Audio) \\
- Unceasing customer service \\
Track the below URL for one-step submission \\
https://juniperpublishers.com/online-submission.php \\
\hline
\end{tabular}

